DOI: $10.1515 /$ pof-2017-0009

VOLUME 9, ISSUE 2, 2017

ISSN: $2036-5438$

\title{
Paradigms for EU Law and the Limits of Delegation. The Case of EU Agencies
}

by

Marta Simoncini*

Perspectives on Federalism, Vol. 9, issue 2, 2017 


\section{Abstract}

This article questions the idea that the $\mathrm{EU}$ is a pure regulatory power based on supranational delegation of competence from the Member States. It claims the insufficiency of this single paradigm to explain the developments of EU law and the need to integrate it with recognition of the constitutional foundations of EU law.

The analysis demonstrates this by focusing on a specific case study of institutional design in the internal market integration: the delegation of powers to EU agencies. By recognising the judicial evolution of the so-called Meroni doctrine concerning the nondelegation of powers to EU agencies, the article unveils that, legally speaking, the enhancement of EU agencies' powers takes place in the autonomous constitutional framework of the EU legal order.

This constitutional foundation of EU law shall therefore complement the supranational delegation paradigm. Only in this wider approach can the legitimacy of EU agencies' powers be framed and accommodated in the composite nature of the EU as a Union of Member States. On these grounds, the final remarks highlight the need for a more comprehensive paradigm for EU law that can explain these different aspects of EU law under a common approach based on a wider public law discourse.

\section{Key-words}

supranational delegation; principle of conferral; EU agencies; Meroni doctrine; accountability 


\section{Introduction}

When understanding the potential and the limits of EU action, the identity of the EU legal order and the nature of the EU integration process matter. The debate about EU integration is a consolidated one. Political science scholarship has been a major contributor to understanding the integration process. The debate has developed also within legal scholarship and it has mainly concerned the legitimacy of the EU legal order. The legal debate has polarised the discussion between the search for the constitutional foundations of an autonomous legal order and the analysis of the cooperation and integration in the multilevel governance. Broadly speaking and simplifying the different aspects of the legal debate, legal scholarship has explored the EU either as a constitutional subject or as a phenomenon of regulatory governance.

When analysing the supranational law framework of the EU, however, these competing approaches do not appear mutually exclusive as the legal debate may have indirectly suggested so far. This article claims that these approaches are complementary and that, individually taken, none of them can capture the real nature of the EU law, but can only contribute to highlighting specific aspects of the EU experience. EU law offers many examples of this hybrid nature of the EU, caught between the constitutional and the regulatory dimensions. I will demonstrate this by focusing on a specific case study concerning of the EU institutional design: the delegation of powers to EU agencies. Despite their governance vocation, EU agencies are conceived and developed as fully supranational actors under EU secondary legislation. They operate in the regulatory sphere, but they require constitutional justification. Their powers are the expression of a specific constitutional experience that finds its roots in the composite nature of the EU legal order.

As the evolution of the Court of Justice (CJEU)'s case law points out, legally speaking the evolution of administrative powers at the EU level cannot be explained through the pure lenses of the supranational delegation from the Member States. The administrative law relationship that EU agencies develop presupposes the development of an autonomous supranational order that constitutionally frames EU agencies' powers. Only the existence of a constitutional principle at the EU level concerning the conditions for the delegation of powers conferred upon the EU institutions to EU agencies explains if and how EU 
agencies may legitimately retain regulatory powers. This principle known as the Meroni doctrine shows the autonomous foundation of the responsibilities and tasks of EU agencies at the supranational level.

The resulting legal framework goes beyond the paradigm of supranational delegation from Member States without disregarding it. A wider paradigm shall cover the complementarities of the different approaches and explain the integration process without losing important aspects of the EU identity. As Cassese (2015) has shown, the openness of public law can create new frameworks for law by combining different levels of regulation and meaningful interactions that generate institutional changes. The recognition of the complementarity of paradigms in the characterisation of the EU legal order may generate this wider public law approach to EU law that includes and reinterprets them in a composite framework.

EU agencies' powers and the guarantees of their exercise need to be designed by considering the original character of the EU legal order, as a Union of Member States. Accountability and legitimacy issues, therefore, shall be addressed not only at the supranational framework of EU powers, but also within the multilevel structure of the EU. This means that not only the Meroni doctrine, but also the supranational delegation paradigm may contribute to re-connecting the EU administrative developments to the legitimate functioning of the EU legal order.

The article is structured as follows. Firstly, it introduces the paradigm of supranational delegation and points out its limits. Subsequently, the constitutional foundations of the Meroni doctrine in the EU legal framework are presented (sec. 3) and the analysis shows how EU law goes beyond the direct link to supranational delegation (sec. 3.1). A wider approach based on the composite nature of EU public law emerges (sec. 4). Political accountability and legal accountability are thus analysed with regard to both the EU and the Member States and their citizens (sec. 5). The final remarks emphasise the need for a more comprehensive public law paradigm to understand the powers of EU agencies and, more generally, the nature of EU law. 


\section{The slippery nature of the EU integration process}

The EU integration process has been explained in different ways. Theories of EU integration have developed different approaches to the issues and the evolution of the EU. Since the 1970s, theories of governance have been developed to explain that specific aspect of the integration process; that is, the supranational integration in the internal market.

When conceiving EU integration as a phenomenon of governance, emphasis is put on the regulatory role of EU institutions and bodies which operate at the EU level. The EU integration process is considered as being based on the delegation of regulatory powers from the Member States to the EU institutions as the result of a broader process of fragmentation and diffusion of normative powers. This reading of EU integration conceives the idea that EU institutions retain regulatory powers, which have been conferred by the Member States with the aim of satisfying functional demands, but upon the condition of retaining oversight over the exercise of the conferred powers.

This approach was first developed by political science scholarship, which emphasised that the technocratic power of the EU was a means for Member States to insulate themselves from political pressures and commit to implementing EU policies (Majone 1990, 1994: 23; 1995 and 1996). Subsequently, the legal scholarship has further explored the governance approach to integration and distinguished the EU as a form of deliberative supranationalism from a constitutional experience. In his scholarship on legal history, Lindseth (2010 and 2014) has particularly described EU integration as an 'administrative' phenomenon, as it regards the conferral of specialised regulatory powers not on the basis of the expression of a general democratic will, but on the grounds of a delegation of powers from nation state institutions.

The rejection of the constitutional foundations is based on a political approach to constitutionalism that emphasises the primacy of the politics embedded in the democratic process (Goldoni 2012: 928-937). The administrative approach to EU integration aims to reconcile the functional demands of economic interdependence for supranational regulatory solutions with the state-based concepts of democratic and constitutional legitimacy. It points out that the construction of the EU lacks political autonomy as it derives its legitimacy from the constitutional systems of its Member States. From this point of view, this approach is linked to the theories which have discussed the political legitimacy 
of the EU as based on the national democratic circuits (Moravcsik 1998; Weiler 1982 and 1991; Nicolaïdis 2004 and 2010).

Lindseth considers the political-cultural nature of such an administrative integration and he presupposes and implies the absence of autonomy of the EU as a (constitutional) legal order. The EU benefits from a 'mediated form of legitimacy', which stems from its Member States and their citizens. Member States are thus understood as the principals overseeing the EU, the agent. European integration is not conceived as a phenomenon of constitutional law, because the EU legal order excludes a 'true' constitutional foundation, which remains in the domain of the single Member States and is entrenched in the national populations and in the national democratic institutions. According to this paradigm, EU is the expression of administrative governance beyond the state based on the voluntary decision of national states to delegate powers and pre-commit to the law that such delegation entails (Lindseth 2014: 534 and 549). From a political-historical standpoint, the EU results in something different from a constitutional phenomenon as it rests upon the transfer of powers to supranational institutions from the Member States which democratically retain them.

Building upon the same bottom-up approach to EU integration, however, different theories of constitutionalism can reverse these conclusions. Admitting that the legitimacy of the EU rests upon the democratic constitutions of the Member States, EU law may appear as an experiment of multilevel constitutionalism based on a plurality of national constitutions committed to a supranational constitutional experience (Pernice 1999; Walker 2009). It has also been considered as a process of constitutional synthesis, founded on the supranational reinterpretation of Member States' constitutional and institutional structures (Menéndez and Fossum 2011; Milwald 1992; for a critical approach see Goldoni 2014).

When claiming that the EU and particularly the European Monetary Union (EMU) is not based on 'political constitutionalism', but rather on 'republican intergovernmentalism', Bellamy and Weale (2015: 269-270) share Lindseth's interpretation of EU governance. These scholars consider that the commitment to EMU rests upon political democracy at national levels which provide governments with the necessary (democratic) legitimacy to enter into credible commitments. They also observe that this is confirmed by the decisions of the German Constitutional Court: the legitimacy of the German state's commitment to EU goals and policy is legitimate as long as it is consistent with the principles of the 


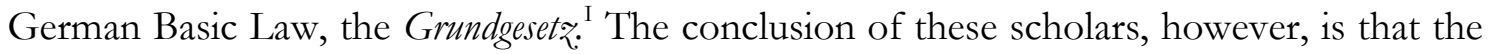
EMU is an experiment of legal constitutionalism -rather than one of administrative governance- because it provides a set of legal rules which 'constrain the action of politically responsible decision-makers' and 'disregard [...] the existence of reasonable differences in political judgment over the principles that should govern a monetary union made up of different sovereign states, each with their own traditions of economic and monetary policy' (Bellamy and Wale 2015: 259-260).

This variety of interpretations highlights the intrinsic difficulty of classifying the construction of the EU from a single legal point of view. If the theory of supranational delegation can describe EU integration in the internal market from a political and historical perspective, it cannot capture the development of the EU as an autonomous legal order in the discourse of its own institutions. Legally speaking, the comprehension of European integration cannot be clearly reduced and limited to a manifestation of a specific area of national law. Interferences between different law domains are at the heart of the slippery legal nature of the EU legal order. When looking at EU law as a supranational experiment of administrative governance beyond nation states, some autonomous developments of the EU institutional design and regulatory framework cannot be easily reconnected to this approach. Through the Principal-Agent theory 'supranational autonomy is primarily a function of the control mechanisms established by member states to control their international agents' (Pollack 1997: 119). As Pollack highlighted, however, this theoretical framework is not fully supported by institutional developments which jeopardise the model by presenting unexpected situations where supranational institutions can creatively exercise their autonomy (Pollack 1997: 106-107 and 128-130). ${ }^{\mathrm{II}}$ As the scholarship of historical institutionalism has observed, EU institutional design depends on the choices that Member States are willing to make, both at the supranational level and in intergovernmental settings, but then it produces autonomous effects - also unintended - which bind the Member States themselves and their future options (Pierson 1996: 147-148; Scharpf 1998: Verdun 2015: 230-232). Scholarship of intergovernmentalism also noted that Member States negotiate and decide within an integration framework which is path-dependent from an institutional setting with endogenous interdependency and preferences (Schimmelfenning 2015: 192).

Legally speaking, the theory of supranational delegation may build upon an administrative law assumption, but then it produces significant constitutional effects at the 
EU level. This clearly emerges when analysing how EU law has embodied the delegation principle in the principle of conferral, as set in art. 5 TEU:

'1. The limits of Union competences are governed by the principle of conferral. The use of Union competences is governed by the principles of subsidiarity and proportionality.

2. The Union shall act only within the limits of the competences conferred upon it by the Member States in the Treaties to attain the objectives set out therein. Competences not conferred upon the Union in the Treaties remain with the Member States.'

The principle rests upon the transfer of competences from sovereign Member States to the EU, but within the domain of the devolved competences then the $\mathrm{EU}$ is only committed to the implementation of the Treaties and the exercise of its powers is only limited by the principles of subsidiarity and proportionality as set in EU law. The oversight of Member States is therefore constrained by the rule of the Treaties which thus founded the constitutional legitimacy of the EU legal order and its institutions. If the oversight of Member States is mediated by the Treaties and their institutions, the linearity of the supranational delegation paradigm is not able by itself to explain the developments in the interpretation and the autonomous evolution of EU powers within the framework of the Treaties.

As Weiler (1991: 2407) has observed, the EU appears to be as a 'specified interstate governmental structure defined by a constitutional charter and constitutional principles'. Legally speaking, EU case law clearly affirms the constitutional nature of the EU as an autonomous community based on the rule of law and the protection of fundamental rights. ${ }^{\text {III }}$ It also shows that when applying the principles of proportionality and subsidiarity, as well as when recognising the competences falling within the EU domain, the Court of Justice of the EU has adopted a standard of review which favours further developments of EU action and responsibilities (Craig 2012: chapters 14, 19-20; Weatherill 2011; Harbo 2010; Schütze 2009: 250; Tridimas 2006: chapters 3-4; Kumm 2006; Estella 2002; de Búrca 1999). Without this peculiar constitutional nature of the Treaties, the further development of EU powers beyond the supranational delegation from the Member States cannot be legally explained. 
When understanding EU law, the idea of a supranational administrative governance shall be complemented by and adjusted to the existence of an autonomous dimension of the EU legal order which cannot be explained by the delegation of administrative powers from the Member States, but needs to be understood within the particular categories of EU law. These are two faces of the same coin: if you look from the perspective of the Member States, you must admit that they have politically accepted to confer part of their powers upon supranational institutions and you can conceive the transferred powers as regulatory in nature; but if you look from the perspective of EU institutions then you see an autonomous supranational legal order which is committed only to the goals set in the Treaties and which binds Member States and shapes their individual legal orders according to the framework of the Treaties. When doing this, unforeseen legal instruments and new regulatory solutions can be autonomously developed under the framework of EU law.

The legal potential embedded in the EU legal order shows that a gap exists between the political dimension of the EU integration and the legal one. The political sovereignty of the Member States does not correspond to their legal sovereignty. EU law creates effective constraints and allocates fundamental rights which affect both states and individuals. The challenge is how to reconcile the political and legal dimensions. Administrative governance as such is not able to effectively fill this gap. Only a broader understanding of how to reconnect the supranational delegation of competences from the Member States and the autonomous supranational developments of EU law can do that.

\section{EU agencies in the supranational foundations of $\mathbf{E U}$}

The autonomous development of the EU law has produced constitutional principles and institutional structures that affect the decision-making in the Member States and commit them to the enforcement of EU law. Under EU administrative law, supranational phenomena of administrative governance are justified in the light of the Treaties as interpreted by the Court of Justice. In the silence of the Treaties about the possibility to delegate powers to EU agencies, the Court of Justice has set the constitutional constraints that kept these bodies within the EU legal framework. These constraints represent the legal justification of EU agencies' powers and make delegation a phenomenon of pluralisation and specialisation of EU powers. If supranational delegation may be considered a 
preliminary condition for the delegation of powers to EU agencies, it cannot explain neither whether nor to what extent delegation to EU agencies may be legally possible and necessary. A contrario, this means that the legal substance of supranational delegation is shaped by the autonomous evolution of the EU legal framework. Because of this autonomous dimension of EU public law, the content of the principle of conferral has changed and new regulatory instruments have been developed under EU law.

The growth of EU agencies' powers in the internal market is the consequence of the need for specialisation and technical expertise in some domains where EU law should be developed and implemented (Hofmann and Morini 2012: 421-423; Groenleer 2009: 100108; Magnette 2005: 7-10). However, this functional development of EU law has been legally constrained by the principle of conferral as set in the Treaties and interpreted by the Court of Justice. The principle of conferral shaping the (political) delegation of competences to EU institutions has the supranational effect of designing a system of division of powers at the EU level which cannot be arbitrarily changed by EU institutions.

The non-delegation doctrine that generally goes under the label of the Meroni doctrine has defined the legal limits to the growth of EU agencies' powers. ${ }^{\text {IV }}$ The concern of this doctrine is the protection of the balance of powers as set in the Treaties: conferred responsibilities cannot shift from the EU institutions that legitimately retain competences to other bodies outside the relation of supranational delegation from the Member States. If this is the substantive issue, however, the evolution of EU case law on EU agencies' powers demonstrates that the balance of EU powers depends on the autonomous legal developments of the EU legal order. The connection with the Member States through the principle of conferral does not prevent EU law from implementing autonomous instruments of governance in the internal market. The real issue of delegation at the EU level concerns the constitutional status of EU agencies, on the one hand, and the nature and the guarantees about how these agencies exercise powers, on the other hand. As soon as some changes had intervened in these regards, the limits to the conferral of tasks on EU agencies also changed in the interpretation of the Court of Justice.

By analysing the evolution of the Meroni doctrine, I will demonstrate that legally speaking, the EU presents original characteristics as an autonomous legal order. The legal constraints to EU agencies' powers are not at the disposal of the Member States and it rests upon the judicial review of the constitutional framework of the EU. Inasmuch as the 
legitimacy of EU agencies' powers is located in the autonomy of the EU legal framework, only legal procedures and remedies can legally reconnect the exercise of EU agencies' powers to the supranational delegation theory. The following sections will show how the judicial interpretation of the Meroni doctrine evolved in almost sixty years of integration according to the Treaties and their interpretation.

\subsection{Addressing EU agencies' powers through the lens of the Meroni doctrine}

The allocation of powers to EU agencies is a clear example of the legal autonomy of the EU from its Member States. Unlike the case of EU institutions, only recently have EU agencies been recognised as institutional actors under the Treaties. Before the Lisbon Treaty, agencies were not included in the Treaties, falling outside the principle of conferral (Lenaerts 1993). Legally speaking, the evolution of their powers is connected to the exclusive development of the EU legal order.

To preserve the allocation of competences as set in the Treaties and not to alter such legal framework, the CJEU developed in the Meroni doctrine the rules for reconciling the need to keep the structure of the supranational legal order unchanged, with the need to delegate technical tasks to expert supranational bodies. This case law is based on the principle of the balance of powers as the other-face of the principle of conferral. The competences of EU institutions cannot be altered by further delegation of tasks implying the exercise of political discretion to bodies not included in the Treaties. By making the institutions able to act only in accordance with the powers they have been conferred by the Treaties, this principle further specifies the more general principle of division of powers within the framework of the European legal order (Jacqué 2004: 383-384). Under the ECSC Treaty, Meroni questioned the delegation of power from the High Authority to two bodies under the Belgian private law - the so-called Brussels agencies - for dealing with financial arrangements of the ferrous scrap regime. In doing this, the Meroni case set the necessary principles and conditions under which any delegation of powers from institutions may be feasible (see Tridimas 2010: 241-243; Tridimas 2012:60-62).

The case held that delegation should find its structural limit in the impossibility of delegating those powers whose exercise requires a discretionary evaluation, since this involves a shift of responsibility not expected by the Treaty. In the Meroni case, the concept of wide discretion referred to a quasi-legislative power 'which may, according to the use 
which is made of it, make possible the execution of actual economic policy'. In addition, the delegation of powers should be explicit and in line with the principle of conferred competences: if necessary for the accomplishment of its tasks, ${ }^{\mathrm{VI}}$ the delegating authority can only provide an agency with powers explicitly ${ }^{\mathrm{VII}}$ and within the limits of the powers it retains. Tridimas (2012: 60-62) has identified in the necessity requirement the further condition of proportionality for lawful delegation. These tasks should then be performed by the agencies under the same conditions as the delegating authority would have performed them. This means that the execution of the delegated tasks should be subject to the same procedural guarantees to be applied by the delegating authority as a necessary condition for its legitimacy.

Subsequently, the non-delegation doctrine has been further developed in the Romano case. Under the EEC Treaty, Romano questioned the delegation of regulatory powers from the Council to a body established under EC secondary law, the Administrative Commission on Social security of Migrant Workers. In a preliminary ruling, the CJEU held that agencies cannot impose methods, interpretative rules or obligations to national administrations, but they can only help such national administrations by providing non-binding decisions, ${ }^{\text {VIII }}$ so as to specify that agencies cannot exercise any rule-making power, but they can only have recommendatory powers.

Only executive powers could thus be delegated from Treaty-based institutions to agencies and their use must be entirely subject to the supervision of the delegating institution. This has been interpreted as holding that no regulatory power can be delegated to agencies without prejudicing the design of powers as set in the Treaties. Administrative rule-making has therefore been frozen with the aim of keeping the institutional structure unchanged and compliant with the principle of conferral. In this line, the non-delegation doctrine has become a constitutional principle of the EU legal order concerning the possible allocation of public powers.

Nonetheless, insofar as internal market development and its proper functioning require those administrative functions to be performed by supranational administrations, an increasing number of agencies have been performing functions that substantially touch upon a regulatory content. Even if formally these agencies have limited powers and issue opinions or draft technical standards to EU institutions or recommendations to Member States, they often retain powers that stretch the Meroni doctrine. The European Aviation 
Safety Agency (EASA), for instance, issues standards which effectively commit Member States to the implementation of EU regulation in the aviation sector (Simoncini 2015a). More recently, the European Supervisory Authorities in the financial markets (ESAs) have been bestowed with more intense powers of supervision and regulation which were reviewed by the Court of Justice according to the Meroni doctrine (Simoncini 2015b).

The recent ESMA - short selling case has somehow opened the door to further EU administrative integration through the development of EU agencies' regulatory powers. ${ }^{\text {IX }}$ The case concerned the ESMA's power to prohibit or impose conditions on the entry by natural or legal persons into transactions in the short selling market or require such persons to notify or publicise their positions, if and when there is a threat to the orderly functioning and the stability of financial markets with cross-border implications; and no competent authority has already taken measures to address such threat. ${ }^{\mathrm{X}}$

When reviewing the compatibility of European Securities and Markets Agency (ESMA)'s powers with the Meroni doctrine, the CJEU updated the Meroni doctrine to the changed constitutional framework which emerged in the Lisbon Treaty. Firstly, the Treaty on the Functioning of the European Union (TFEU) has recognised agencies as legal actors within the EU legal order. ${ }^{\mathrm{XI}}$ Italian administrative law scholarship has assessed this as the end of the precondition on which the Meroni doctrine was based; that is, the absence of any constitutional foundation for agencies' powers (Sorace 2012: 53). Furthermore, the TFEU holds that legal remedies apply also to EU agencies' acts when 'intended to produce' legal effects on third parties and this makes explicit the principle of judicial review already present to the EU judiciary. ${ }^{\text {XII }}$ Against this changed constitutional backdrop, the CJEU confirmed the validity of the logic of non-delegation of discretionary powers, but it 'mellowed' Meroni (Pelkmans and Simoncini 2014), whereas it probably set aside Romano.

The CJEU recognised that the EU legislative power may legitimately confer administrative powers to EU agencies under defined conditions. The CJEU upheld the rules about delegation of powers defined in the Meroni case, but noticed that the allocation of direct supervision powers potentially involving a regulatory impact was grounded on well-restricted conditions which make the discretionary power of intervention subject to strict exercise and effective judicial review. Against the changed backdrop of the Treaties, the Court delineates a form of administrative discretion which is situated between the mere 
executive powers (exercised in completely bound administrative activities) and the "wide margin of discretion', political in nature, at stake in the Meroni case. ${ }^{\text {XIII }}$

The CJEU held that it is in the full power of the EU legislature -as composed of the EU Parliament and the Council through the ordinary legislative procedure ex art. 289 TFEU- to confer implementing powers on EU agencies. This demonstrates the autonomy of the EU legal order, as the EU legislature may confer powers of administrative nature not specifically allocated to EU institutions by the Treaties, on third bodies legally included in the Treaties. Even if the Council is composed of its Member States, nonetheless this is a different framework from the one of supranational delegation. Both the nature of the EU legislature and the nature of the powers in question are different. The EU legislature is a different institutional actor, whose acts are the result of a deliberative procedure of two EU institutions, the European Parliament and the Council. Moreover, the powers conferred on EU agencies express administrative competences that are directly exercised at the supranational level and aimed at the internal market integration. However, to keep the conferral of these powers in line with the principle of institutional balance, guarantees about their nature and their exercise shall apply. Only because of these guarantees could the Meroni case law be mellowed.

Administrative discretion shall be subject to a series of criteria and conditions set in legislative acts which limit and guide the exercise of administrative powers. This is clear from the ESMA - short selling case: the powers conferred on ESMA are not autonomous, but should be exercised according to the relevant regulations conferring the direct supervision powers and more specifically 1 ) only if a concrete risk to the financial stability is at stake and no competent national authority has intervened; 2) by taking into account a number of factors delineated in the short-selling regulation so that ESMA's intervention does not create further risks in the financial markets (e.g., the risk of regulatory arbitrage, or the risk of reduction of liquidity or the creation of further uncertainty on the market); 3) by limiting the power of intervention to temporary and precise measures as outlined in the founding regulation; and 4) by notifying the competent national authorities.

As long as the Court recognises that the TFEU 'expressly permits Union bodies, offices and agencies to adopt acts of general application', the generally valid Romano principle cannot apply anymore to the specific case of EU agencies. ${ }^{\mathrm{XIV}}$ When setting the guarantees of judicial review, the TFEU only indirectly recognises the capability of EU 
agencies to adopt acts of general application. Firstly, when addressing the plea of illegality by guaranteeing the inapplicability of acts of general application to specific proceedings, article 277 TFEU implicitly recognises that agencies can issue acts of general applications. Article 267 b) TFEU on the preliminary ruling addresses the interpretation of the acts of agencies and bodies as well as those of the institutions; furthermore, according to article 265 TFEU, the failure to act can be contested to agencies as well, under the same conditions that apply to EU institutions. Nonetheless, these provisions admit that acts of general application are now in the domain of EU agencies.

What the ESMA - short selling case did was to recognise the new constitutional status that EU agencies achieved in the Treaties: to the extent that they laid down guarantees about the exercise of their powers, the CJEU could mellow the former severity of the Meroni doctrine without dismissing its general structure.

This judicial development shows that the evolution of the constitutional framework of the EU Treaties can give rise to administrative organisations of powers which are supranational in character and cannot be reconnected to the will of the Member States to delegate competences to the EU. It is the EU legislature in its functional autonomy which may create administrative competences at the EU level (within the scope of the Treaties). Such a judicial development of EU administrative law shows the autopoiesis of the EU legal order as an autonomous constitutional subject. However, the theory of the original delegation of powers from the Member States to the EU shall assist in structuring the accountability and strengthening the legitimacy of EU agencies' powers.

\section{Reconnecting EU agencies to the democratic principle}

The judicial evolution of the Meroni doctrine shows that from a supranational perspective, the EU is a legal order autonomous from its constituent Member States. The tasks of EU agencies evolved because of legitimate delegation by the EU legislature on the grounds of political choices made at the EU level.

Under the rule of law, the way the integration works is somehow different from pure delegation of administrative functions from the Member States. This is a means to integration, but the EU legal order has been constructed so that it can autonomously 
develop its own functions within the limits of the Treaties. The oversight of the Member States, therefore, is subject to the autonomous functioning of the EU.

When looking at the growing powers and legitimacy of EU agencies, such autonomous developments of EU administrative law may have great potential for supranational integration in the internal market as well as side effects on the democratic accountability of the EU. The EU administrative framework can have a strong impact on effective harmonisation in the internal market, but it is also clearly disconnected from the national democracies adhering to the EU. As political science scholarship has underlined, this mismatch may raise significant trade-off issues between efficiency and legitimacy in the implementation of EU agencies' tasks (Egan 1998: 499-501).

Administrative law can help to fill the accountability gap and put in place effective mechanisms of control over EU agencies' powers. The implementation of administrative law guarantees beyond the state can help to circumscribe the growth of powers at the EU level and contain the distance of these bodies from national democracies. However, EU administrative law has not provided effective answers yet. It has not yet recognised the relevance and the role of administrative discretion and, consequently, has not developed a coherent accountability system that consistently frames supranational administrative action. As Chiti observed (2016: 587-591), when dealing with administrative power, EU administrative law has focused on how to functionalise it to the implementation of EU law, but it has not been concerned with the establishment of a conceptual framework aimed at understanding the exercise of administrative powers in conformity with the rule of law and democracy. The reason for this failure lies in the disconnection of the development of EU administrative law from its political roots and in its reduction to a functional means of integration.

\section{The commitment to accountability}

When looking at EU agencies' powers from the EU level, the existence of legal remedies to their action and of a framework of political accountability to the EU legislature shall shape the exercise of their powers. When looking at the same issue from the perspective of the Member States, procedural rules can limit and guide the exercise of agencies' powers $^{\mathrm{Xv}}$ as well as the existence of organisational arrangements which allow a 
representation of Member States' interests in the agency's boards. In the current framework of EU agencies, these variables are articulated in different ways and not all are fully developed and in place. I will point out the criticalities of these legal arrangements with the aim of showing the difficulties when reconciling the political and legal dimensions.

When discussing the political accountability framework, the delegation of regulatory tasks to EU agencies shall be supervised by the EU legislature through the enforcement of accountability mechanisms which allow the legislature to check that the exercise of the conferred administrative powers is in line with the mandate. Both ex ante and ex post mechanisms shall operate and ensure that EU agencies exercise only administrative powers within the scope of their remit. According to the (even revised) Meroni doctrine, any in blanc delegation of powers that implies a full shift of responsibilities cannot be legitimate, as far as delegation shall not involve a loss of responsibility for EU institutions, but only a further refinement of their tasks. Besides the definition of clear conditions for the exercise of powers, however, the ex ante control of the EU legislature is not remarkable in the current framework of EU agencies' powers. On the contrary, agencies intervene autonomously and the counterparts of their action are directly the Member States' agencies and private parties operating in the sector of reference.

In this regard, the presence of representatives of the Member States on the management boards of EU agencies might help to find more sustainable regulatory solutions which take into account the diversification of national contexts. Empirical research has not provided conclusive findings on the effects of de jure or de facto vertical accountability mechanisms connecting members of the management boards and the correspondent national institutions. Findings express some variance; but today these mechanisms are not able to effectively reconnect EU agencies to the national political legitimacy (Buess 2015: 101-107). ${ }^{\mathrm{XVI}}$

The presence of national representatives on the management boards may also hamper EU agencies' autonomy and delay the exercise of agencies' powers in favour of more concerted measures which may not have the same effectiveness. In the case of the ESAs, for instance, adjudication powers aimed at requiring the competent national authorities to take the necessary action in accordance with EU law and if necessary, at substituting the competent national authorities' decisions and making decisions directly applicable to financial institutions, ${ }^{\mathrm{XVII}}$ have never been exercised in the five years since their foundation. 
One reason for the failure to fully use supervisory powers shall be found in the structure of the governance of the ESAs. As their board of supervisors is composed of representatives of the national competent authorities, before the adoption of restrictive measures addressed to the same national authorities, they preferred to pursue the supervisory convergence goal by using non-binding mediation, persuasion and reputational instruments which are less burdensome on the addressed national competent authorities. ${ }^{\text {XVIII }}$

Ex post accountability mechanisms operate with the EU legislature and mainly consist in the submission of an annual report to the European Parliament and the Council which shall give account of the activities carried out. ${ }^{\text {XIX }}$ If the annual report is the traditional method used to ensure the accountability of independent agencies in the Member States, the highly technical nature of reports does not allow a substantive control of the EU legislature on the performance. For instance, a concise version of the report in layman terms could be usefully submitted, so as to enhance the understanding of EU agencies' activities and allow politicians to effectively know the methods and to see the results of EU agencies' performances.

This accountability framework shows that the EU legislature substantially confers powers on EU agencies, but it is not equipped with effective control powers. In this light, it is not by chance that the 2012 Common Approach has introduced an 'alert/warning system' to be activated by the Commission if it has 'serious reasons for concern' that an EU agency may act beyond its mandate, may violate EU law or may be in manifest contradiction with EU policy objectives' ${ }^{\mathrm{xx}}$ If the EU agency does not accommodate the Commission's request, the latter informs the European Parliament and the Council with the aim of settling the institutional conflict. Vos (2014: 32-33) has suggested that this provision might be susceptible to introducing a form of 'ministerial responsibility for agencies' acts' in relation to EU commissioners. The search for complementary accountability instruments that beyond their specific goals can set up a wider political accountability framework is key to reconnecting EU agencies to the composite nature of the EU and to consolidate their legitimacy.

Alongside the political accountability framework, legal accountability can also play a significant role and limit possible illegitimate use of administrative powers. As seen, the existence of effective judicial protection is a necessary pre-condition for the allocation of powers to EU agencies. The nature of the judicial scrutiny on administrative acts is key 
(Türk 2013). The question is what level of deference the judiciary takes towards EU agencies' acts when complex technical assessments are submitted to the judicial review. ${ }^{\text {xx }}$ Clearly, the scrutiny on facts, the compliance with the criteria of delegation and the enforcement of procedural rights when taking administrative measures and acts are essential elements for making the judicial review effective. In the EU courts' case law, when complex technical assessments are at stake, courts cannot substitute their appraisal of the case with the one of the competent institution and judicial review shall focus on how the discretionary powers have been applied.

Since the leading case Technische Universität München, the criteria for such a control have been consolidated and judicial review has consisted of how the competent authorities have performed 'the duty (...) to examine carefully and impartially all the relevant aspects of the individual case' ${ }^{\text {XxII }}$ Judicial review therefore consists of scrutiny of the law and the facts which grounded the decision in question, as well as of procedural review. When applying this standard to EU institutions, the EU courts applied the manifest error standard: as long as EU institutions have not exceeded the bounds of their discretion, only manifest distortions in the exercise of the conferred powers are illegitimate (Craig 2012:408-409 and 441-445; A.H. Türk 2013: 141). ${ }^{\text {XXII }}$ Even if EU agencies have different status from EU institutions, it is reasonable that EU courts apply the same standard of review, but within the different boundaries of (technical) discretion. This means also checking the delegation criteria.

According to Technische Universität München, if the fundamental guarantees of fairness particularly the careful and impartial examination which is closely linked to the right to be heard and the duty to give reasons - ${ }^{\text {xxIV }}$ are not correctly enforced, the legitimacy of the administrative measures shall be successfully challenged. In this regard, if EU agencies were called to follow a common EU administrative procedure, judicial review could be favoured and the exercise of (technical) discretion could be more controlled.

Even if EU agencies adopt their own rules of procedure based on the general principles set in the founding regulations and in the case law, this cannot have the same legal value of a general law about the EU administrative procedure in terms of protection of procedural rights and controls over the exercise of administrative powers. In fact, the choice of procedural rules is not neutral to the final decision. The way the procedure is articulated allows some interests rather than others to be taken into account and this affects both fact- 
findings and decision-making (della Cananea 2004: 207). When leaving the definition of the procedure to EU agencies, the prioritisation of interests itself is left to agencies.

The autonomy with which EU agencies can organise their own administrative procedure seems to be at odds with the allocation of administrative powers of supervision and regulation to actors who are not legitimated through the democratic circuit and are also far from the national demoi. The implementation of procedural guarantees through primary law would positively affect the compliance with the constraints of the (even mellowed) Meroni doctrine. The democratic principles embedded in the Meroni doctrine would benefit from the existence of an administrative procedure law which ensures procedural legitimacy in the exercise of EU agencies' powers. The introduction of an EU administrative procedure law would make the exercise of (regulatory) powers more visible to the Member States as well as to European citizens and sector-operators.

\section{Final remarks. In need for a public law paradigm for EU law}

By analysing the evolution of EU agencies' powers, this article aimed to point out the complexity of the EU identity and the insufficiency of single paradigms to explain the hybrid nature of the EU legal order. The autonomy of the EU legal order and its derived legitimacy from the constituent Member States emerged as faces of the same legal reality. From a legal point of view, the powers and the limits of the EU legal order exceed the classification as an experiment of administrative governance, but at the same time the legal autonomy of the EU cannot disregard the national dimensions when developing its own dimension.

The complex foundations of their powers rests upon the evolution of the Meroni doctrine in the EU case law. When setting the constitutional principle of the limits to delegation of EU institutions' powers to other entities, the CJEU has demonstrated it is sensitive (only) to the mutation of the constitutional framework of the Treaties. Only when EU agencies acquired a constitutional status and their powers have been subject to defined conditions and explicitly recognised as amenable to judicial review, have they become legitimate actors able to exercise implementation powers with a regulatory impact.

When considering the 'mediated legitimacy' of the EU as envisaged by the administrative paradigm of EU integration, EU agencies' powers cannot be explained as a 
supranational delegation experience. They can be interpreted as further fragmentation of national normative powers which involves a relaxation of Member States' oversight aimed at the development of the (supranational) internal market. However, this development is legally justified only according to the autonomous framework of EU law. The legal inconsistency of supranational delegation to explain such a specific development of EU law demonstrates that the administrative paradigm, based on supranational delegation from the Member States, may not be sufficient to encompass this institutional aspect of EU law. A wider paradigm is therefore needed; a paradigm that can also cover the autonomous developments of EU law.

The instruments of public law may provide the useful approach, giving a good measure of the different aspects of EU law. Under a public law paradigm, the compatibility of EU agencies' powers may be assessed within the framework of EU law as an autonomous legal system composed of the Member States. The legitimate powers of EU agencies shall be compatible with the principle of conferral as set in the Treaties and thus with the balance of powers within the EU. Benchmarks of the compatibility of EU agencies' powers can be identified through administrative law instruments which can re-connect the supranational administration to EU institutions, as well as to the Member States.

The balance of EU powers can be implemented by strengthening the political accountability framework and by settling possible illegitimate alterations through judicial review. From the perspective of the Member States, organisational arrangements and procedural restrictions to the exercise of EU agencies' powers can help to administratively protect against any unwanted extension of EU regulatory tasks. Procedural arrangements also protect individual citizens against arbitrary decisions of EU administrative bodies. Administrative law can thus provide the instruments for containing an unnecessary proliferation of administrative agencies.

As seen, not all these arrangements are in place and their effectiveness may be strengthened, so as to implement new benchmarks for the Meroni doctrine. If more regulatory powers are conferred upon EU agencies, the implementation of these arrangements would become a preliminary condition that allows to maintain in equilibrium the different elements that compose the EU legal order.

EU law as a specific experience of public law presents an original character where the administrative dimension is embedded in the constitutional structure of the Treaties and 
both these aspects contribute to explaining and nourishing the EU integration process. The constitutional status of the EU is not structured as in the Member States through the traditional state doctrine, but nonetheless it is legally enforceable and it also frames supranational administrative governance.

The administrative approach to EU integration points out the gap between the legal dimension of the EU and its political nature and it recalls the need to safeguard democratic instance in the expansion of EU powers. For this reason, from a pure legal perspective, a public law paradigm for EU integration would contain and respect these different components in a broader framework. A paradigm that is not open to unify these administrative and constitutional aspects is not able to explain the complexity of the EU legal order. As long as administrative law cannot explain the whole reality of the EU legal order, methodologically this means accepting that a single legal discipline cannot explain the EU legal order. Different legal disciplines shall engage in an interdisciplinary dialogue aimed at understanding the nature of the EU in the polymorphous domain of public law. This dialogue would help to approach the EU as a specific public law experience, which can be analysed but not captured through the categories of the single legal disciplines.

\footnotetext{
* The author is an FWO post-doctoral fellow at the University of Antwerp and King's College London. Email: marta.simoncini@uantwerpen.be.

I This is particularly evident in the German Constitutional Court's case law about the existence of equivalent levels of protection of fundamental rights in the so-called Solange saga (Solange I-Beschluß, 29 May 1974, BVerfGE 37, 2712 BvL 52/71; Solange II-decision, 22 October 1986, BVerfGE 73, 3392 BvR 197/83) and about the ratification of Treaties (Brunner v European Union Treaty, 12 October 1993, BVerfGE 89, 155; Lisbon Urteil, 30 June 2009, 2 BvE 2/08, 2 BvR 1010/08, 2 BvR 1022/08, 2 BvR 1259/08, 2 BvR 182/09). More recently, this is clear also from the preliminary references to the Court of Justice (CGEU) on the legitimacy of financial instruments adopted after the crisis (OMT case, 14 January 2014, 2 BvR 2728/13, 2 BvR 2729/13, 2 BvR 2730/13, 2 BvR 2731/13, 2 BvE 13/13, on which the CJEU ruled in the case C-62/14, Peter Gauweiler and Others v Deutscher Bundestag ECLI:EU:C:2015:400).

II Pollack particularly points out that the functionalist approach of Principal-Agent theory cannot predict either the functions delegated to specific institutions, such as the European Parliament which is not the agent of the Member States, or the developments in the exercise of institutions' functions, which may express the preferences of supranational institutions rather than the ones of the Member States.

III See particularly CJEU, Case 294/83, Les Verts v Parliament, 1986 ECR 1339, para 23; CJEU, Joined Cases C-402/05 P and C-415/05 P, Yassin Abdullah Kadi and Al Barakaat International Foundation v Council of the European Union, 2008 ECR I-06351, paras 281-285.

IV CJEU, Case 9/56 and 10/56, Meroni \& Co., Industrie Metallurgiche s.p.a.v High Authority, 1957-1958 ECR 133. v 9/56 and 10/56, Meroni v High Authority, 173.

vi 9/56, Meroni v High Authority, 151; 10/56, Meroni v High Authority, 172.

VII In this regard see also CJEU, Case C-154-155/04, Alliance for Natural Health, 2005 ECR I-6541, para 90; CJEU, Case C-301/02 P, Tralli v ECB, 2005 ECR I-4071, paras 42-52; GC, Case T-311/06, FMC Chemical SPRL $v$ European Food Safety Agency (EFSA), 2008 ECR II-88, para 66, where the General Court rejected the argument that the Commission had delegated to EFSA its powers to adopt decisions having binding effects on third parties on the grounds that 'powers cannot be presumed to have been delegated and that, even when empowered to delegate its powers, the delegating authority must take an express decision to that effect'. It is
} 
interesting that in this latter case the Court does not deal with the legal feasibility of such delegation of powers, so that it does not get to question the validity of the Meroni doctrine.

VIII CJEU, Case 98/80, Giuseppe Romano v Institut national d'assurance maladie-invalidité, 1981 ECR 1259, para 20.

IX CJEU, Case C-270/12, United Kingdom of Great Britain and Northern Ireland v Council of European Union and European Parliament, ECLI:EU:C:2014:18.

x Art. 28 of Regulation 236/2012/EU of the European Parliament and of the Council of 14 March 2012 on short selling and certain aspects of credit default swaps.

XI Art. 298 TFEU.

XII Art. 263 TFEU. See GC, Case T-411/06, Solgema, 2008 ECR II-2771, paras 36-37. This represents a further development in the sector of EU agencies and bodies of the principle of judicial review as a key aspect of the rule of law as held Les Verts case (94/83 Les Verts v European Parliament, 1986 ECR 1339, para 23).

XIII C-270/12, UK v Council and European Parliament, paras 41-42. See also M Scholten and M van Rijsbergen (2014: 394-395).

XIV C-270/12, UKv Council and European Parliament, para 65.

$\mathrm{XV}$ On the role of administrative procedure as a means available to the Principal to ensure the accountability of the Agent see Pollack 1997: 108.

$\mathrm{XVI}$ As the de jure accountability is concerned, Buess notes that the more independent and powerful EU agencies are (like the EMA, EASA, and the OHIM), the less accountable to national institutions they are.

XVII Artt. 17, 18, 19 of the Regulation 1093/2010/EU of the European Parliament and of the Council of 24 November 2010 establishing a European Supervisory Authority (European Banking Authority), amending Decision No 716/2009/EC and repealing Commission Decision 2009/78/EC; Regulation 1094/2010/EU of the European Parliament and of the Council of 24 November 2010 establishing a European Supervisory Authority (European Insurance and Occupational Pensions Authority), amending Decision No 716/2009/EC and repealing Commission Decision 2009/79/EC; regulation 1095/2010/EU of the European Parliament and of the Council of 24 November 2010 establishing a European Supervisory Authority (European Securities and Markets Authority), amending Decision No 716/2009/EC and repealing Commission Decision 2009/77/EC (hereafter: the ESAs' Founding regulations).

XVIII See Report from the Commission to the European Parliament and the Council on the operation of the European Supervisory Authorities (ESAs) and the European System of Financial Supervision (ESFS), COM (2014) 509 fin., 7.

XIx See art. 57, of Regulation 216/2008 of the European Parliament and of the Council of 20 February 2008, on common rules in the field of civil aviation and establishing a European Aviation Safety Agency, and repealing Council Directive 91/670/EEC, Regulation (EC) No 1592/2002 and Directive2004/36/EC; see also art 50, art. 16 (4) and 17 (8), of the ESAs' Founding Regulations, which also require the ESAs to clarify plans and include any information requested by the European Parliament on an ad hoc basis.

xx Common Approach Annex to the Joint Statement of the European Parliament, the Council of the EU and the European Commission of 19 July 2012 on decentralised agencies, para 59.

XXI From this point of view, the American experience is paradigmatic, since in a few years the Supreme Court passed from the deep review of administrative decisions - the so-called hard look doctrine developed in the '70s (see Citizen to Preserve Overton Park v Volpe (1971) 401 US 402; Vermont Yankee Nuclear Power Corp. v National Resources Defense Council (1978) 435 US 519; Motor Vehicle MFRS. ASSN v State Farm (1983) 463 US 29) - to a much more deferential approach in the case Chevron Usa v Council (1984) 467 US 837.

XXII See CJEU, Case C-269/90, Technische Universität München, 1991 ECR I-05469, para 14; see also GC, Case T-13/99, Pfizer Animal Health SA v Council of the European Union, 2002 ECR II-03305, para 171.

XXIII Türk particularly considers the introduction of general provisions concerning the public participation in EU administrative rule-making as a means 'to enhance the legitimacy of the process' and as a method 'to ensure that the Union courts have an adequate administrative record for substantive review'. See CJEU, Case C-331/88, The Queen v Minister of Agriculture, Fisheries and Food and Secretary of State for Health, ex parte: Fedesa and others, 1990 ECR I-04023, para 9; T-13/99, Pfizer Animal Health SA, para 166.

xxIV C-269/90, Technische Universität München, paras 25-26. 


\section{References}

- Bellamy Richard and Weale Albert, 2015, 'Political legitimacy and European monetary union: contracts, constitutionalism and the normative logic of two-level games', Journal of European Public Policy, XXII(2): 257-274.

- $\quad$ Buess Michael, 2015, 'European Union agencies and their management boards: an assessment of accountability and demoi-cratic legitimacy', Journal of European Public Policy, XXII(1): 94-111.

- $\quad$ Cassese Sabino, 2015, 'An International Society of Public Law', ICON S Working Paper Series Conference Proceedings Series 1 No 1.

- Chiti Edoardo, 2016, 'Is EU Administrative Law Failing in Some of Its Crucial Tasks?', European Law Journal, XXII(5): 576-596.

- Cohen Joshua and Sabel Charles, 1997, 'Directly-Deliberative Polyarchy', European Law Journal, III: 313-342.

- $\quad$ Craig Paul, 2012, EU Administrative Law, Oxford University Press, Oxford.

- de Búrca Gráinne, 1999, 'Reappraising Subsidiarity Significance After Amsterdam', Harvard Jean Monnet Working Paper No. 7.

- della Cananea Giacinto, 2004, 'The European Union's mixed administrative proceedings', in Law and Contemporary Problems, 68:197-218.

- $\quad$ Egan Michelle, 1998, 'Regulatory strategies, delegation and European market integration', Journal of European Public Policy, 5:485-506.

- $\quad$ Estella Antonio, 2002, The EU Principle of Subsidiarity and its Critique, Oxford University Press, Oxford.

- Goldoni Marco, 2012, 'Two internal critiques of political constitutionalism', International Journal of Constitutional Law, X(4): 926-949.

- Goldoni Marco, 2014, 'The Gift of Synthesis', European Constitutional Law Review, X(2):359-364.

- Groenleer Martijn L P, 2009, The Autonomy of European Union Agencies. A Comparative Study of Institutional Development, Eburon, Delft.

- Harbo Tor-Inge, 2010, 'The Function of the Proportionality Principle', European Law Journal, XVI(2): 158-185.

- Hofmann Herwig C.H. and Morini Alessandro, 2012, 'Constitutional aspects of the pluralisation of the EU executive through "agencification"”, European Law Review, XXXVII: 419-443.

- Hofmann Herwig C.H. and Türk Alexander H. (eds), 2006, EU Administrative Governance, Elgar Publishing, Cheltenham.

- $383-391$

- Kumm Mattias, 2006, 'Constitutionalising Subsidiarity in Integrated Markets: The Case of Tobacco Regulation in the European Union’, European Law Journal, XII(4): 503-533.

- Lenaerts Koen, 1993, 'Regulating the regulatory process: “delegation of powers" in the European Community', European Law Review, XIX: 23-49.

- Lindseth Peter, 1999, 'Democratic Legitimacy and the Administrative Character of Supranationalism: The Example of the European Community', Columbia Law Review, XCIX(3): 628-738.

- Lindseth Peter, 2010, Power and Legitimacy: Reconciling Europe and the Nation State, Oxford University Press, Oxford.

- Lindseth Peter, 2014, 'Equilibrium, Demoi-cracy and Delegation in the Crisis of European Integration', German Law Journal, XV(4): 529-567.

- Magnette Paul, 2005, 'The Politics of Regulation in the European Union', in Geradin Damien, Muñoz Rodolphe and Petit Nicolas (eds), Regulation through Agencies in the EU. A New Paradigm of European Governance, Elgar Publishing, Cheltenham, 3-22.

- Majone Giandomenico (ed), 1990, Deregulation or Re-Regulation? Regulatory Reform in Europe and the United States, Pinter, New York.

- Majone Giandomenico, 1994, "The European Community. An "Independent Fourth Branch of Government"?', in Brüggemeier Gert (ed), Verfassungen für ein ziviles Europa, Nomos, Baden-Baden, 23-44.

- Majone Giandomenico, 1995, The European Community as a Regulatory State, Nijhoff, Leiden. 
- Majone Giandomenico, 1996, Regulating Europe, Routledge, London.

- Martinico Giuseppe, 2012, The Tangled Complexity of the EU Constitutional Process, Routledge, London

- Menéndez Agustín J. and Fossum John E., 2011, The Constitutional Gift. A Constitutional Theory for a Democratic European Union, Rowman \& Littlefield, Lanham.

- $\quad$ Milwald Alan, 1992, The Rescue of the European Nation-State, Routledge, London.

- Moravcsik Andrew, 1998, The Choice for Europe: Social Purpose and State Power from Messina to Maastricht, Cornell University Press, Ithaca.

- Nicolaïdis Kalypso, 2004, 'The New Constitution as European 'Demoi-cracy'?', Critical Review of International Social and Political Philosophy, VII(1): 76-93.

- $\quad$ Nicolaïdis Kalypso, 2010, 'Sustainable Integration: Towards EU 2.0?', Journal of Common Market Studies, XLVIII(1): 21-54.

- Pelkmans Jacques and Simoncini Marta, 2014, 'Mellowing Meroni: How ESMA can help build the single market', CEPS Commentary, available at http://www.ceps.eu/system/files/Mellowing\%20Meroni.pdf.

- $\quad$ Pernice Ingolf, 1999, 'Multilevel Constitutionalism and the Treaty of Amsterdam', Common Market Law Review, XXXVI(4): 703-750.

- $\quad$ Pernice Ingolf, 2009, 'The Treaty of Lisbon: Multilevel Constitutionalism in Action', Columbia Journal of European Law, XV(3): 349-407.

- Pierson Paul, 1996, 'The Path to European Integration. An Historical Institutionalist Analysis', Comparative Political Studies, XXIX(2): 123-163.

- Pollack Mark A., 1997, 'Delegation, agency, and agenda setting in the European Community', International Organization, LI(1): 99-134.

- Schimmelfenning Frank, 2015, 'Liberal intergovernmentalism and the euro area crisis', Journal of European Public Policy, XXII(2): 177-195.

- Scholten Miroslava and van Rijsbergen Marloes, 2014, 'The ESMA-Short Selling Case. Erecting a New Delegation Doctrine in the EU upon the Meroni-Romano Remnants', Legal Issues of Economic Integration, XLI(4): 389-405.

- $\quad$ Schütze Robert, 2009, From Dual to Cooperative Federalism: The Changing Structure of European Law, Oxford University Press, Oxford.

- $\quad$ Scharpf Fritz W., 1988, 'The joint decision trap: Lessons from German federalism and European integration', Public Administration, LXVI(3): 239-278.

- Simoncini Marta, 2015a, 'The erosion of the Meroni doctrine. The case of the European Aviation Safety Agency (EASA)', European Public Law, XXI(2): 309-342.

- Simoncini Marta, 2015b, 'Legal boundaries of the European Supervisory Authorities (ESAs) in the financial markets. Tensions in the development of true regulatory agencies', Yearbook of European Law, XXXIV(1): 319-350.

- $\quad$ Sorace Domenico, 2012, 'Una nuova base costituzionale europea per la pubblica amministrazione', in Chiti Mario P. and Natalini Alessandro (eds), Lo spazio amministrativo europeo. Le pubbliche amministrazioni dopo il Trattato di Lisbona, Il Mulino, Bologna, 45-85.

- $\quad$ Tridimas Takis, 2006, General Principles of EU Law, Oxford University Press, Oxford.

- Tridimas Takis, 2009, 'Community Agencies, Competition Law, and ECSB Initiatives on Securities Clearing and Settlement', Yearbook of European Law, XXVIII(1): 216-307.

- Tridimas Takis, 2012, 'Financial Supervision and Agency Power: reflection on ESMA', in Nic Shuibhne Niamh and Gormley Laurence W. (eds), From Single Market to Economic Union: Essays in Memory of John A Usher, Oxford University Press, Oxford, 55-83.

- Türk Alexander H., 2013, 'Oversight of Administrative Rulemaking: Judicial Review', European Law Journal, XIX(1): 126-142.

- Verdun Amy, 2015, 'A historical institutionalist explanation of the EU's responses to the euro area financial crisis’, Journal of European Public Policy, XXII(2): 219-237.

- Vos Ellen, 2014, 'European Agencies and the Composite EU Executive', in Everson Michelle, Monda Cosimo and Vos Ellen (eds), European Agencies in between Institutions and Member States, Kluwer, Alphen aan den Rijn, 11-47. 
- Walker Neil, 2009, 'Multilevel Constitutionalism: Looking Beyond the German Debate', LEQS Paper No. 8.

- Weatherill Stephen, 2011, 'The Limits of Legislative Harmonization Ten Years after Tobacco Advertising: How the Court's Case Law has become a "Drafting Guide", German Law Journal, XII(3): 827864.

- Weiler Joseph H.H., 1982, 'The Community System: The Dual Character of Supranationalism', Yearbook of European Law, I(1): 267-306.

- Weiler Joseph H.H., 1991, 'The Transformation of Europe', Yale Law Journal, C(8): 2403-2483. 